\title{
Poverty Reduction, Inequalities and Human Development in the BRICS: Policies and Outcomes
}

Diego Maiorano and James Manor

This paper assesses headway made by governments in Brazil, India, China and South Africa in pursuing three goals: reducing income poverty; reaching the poorest of the poor; and reducing inequality. Outcomes vary as we move up the ladder from the first and easiest of these challenges to the third and most daunting. Then the definition of poverty is broadened to include severe shortage of opportunities, liberties and capabilities. The paper discusses how the four countries performed in ameliorating several human development indicators and in enhancing poor people's 'political capacity', the lack of which is an important dimension of their poverty.

Key words: poverty, inequality, the poorest, social policy, political capacity

Authors' details:

Dr. Diego Maiorano (Corresponding author)

Institute of Asia Pacific Studies

School of Politics and International Relations

University of Nottingham

Contact details: LASS Building, University Park, NG72RD, Nottingham

diego.maiorano@nottingham.ac.uk

Professor James Manor

Institute of Commonwealth Studies,

School of Advanced Study,

University of London,

Senate House,

Malet Street, London WC1E 7HU.

james.manor@sas.ac.uk.

This work was supported by the Economic and Social Research Council under Grant

ES/J012629/1. 


\title{
Poverty Reduction, Inequalities and Human Development in the BRICS: Policies and Outcomes
}

\author{
Diego Maiorano and James Manor
}

In 1990, 1.95 billion people in the world lived in extreme poverty; in 2012 the number had dropped to 896 million. ${ }^{1}$ Brazil, India, China and South Africa are responsible for much of this drastic reduction in global poverty and for the achievement of the first Millennium Development Goal: ${ }^{2}$ collectively, these four countries lifted nearly 800 million people out of extreme poverty. ${ }^{3}$

That occurred, in part, because of economic growth, but social programmes also played a major role. The articles in this special issue look at the political and policy processes that accompanied the emergence of a stronger, less incomplete and more inclusive welfare state in the four countries. This contributed substantially to the marked reduction in income poverty and, equally importantly, to improvements in a number of human development indicators.

This article has a more limited ambition. It will first offer a brief overview of the types of programmes that were introduced or expanded in the four countries aimed at tackling poverty and/or inequality. It will then proceed to examine the economic context in which the expansion of those programmes in the four countries has taken place. It will also assess headway made by the governments of Brazil, India, China and South Africa in pursuing three goals: i) reducing income poverty; ii) reaching the poorest of the poor; and iii) reducing inequality. As we will see, outcomes vary as we move up the ladder from the first and least difficult difficult of these three challenges to the third and most daunting where only Brazil has made substantive progress. In the final section, broadening our definition of poverty to include not only a severe shortage of incomes and wealth, but also a lack of opportunities, liberties and capabilities, we will discuss how the four countries performed in ameliorating a number of human development indicators and in enhancing poor people's 'political capacity', which is an important dimension of their poverty.

\section{Expanding social programmes: an overview}

The initiatives either introduced or expanded in the four countries belong to three broadly defined types. The first is a set of social assistance programmes. Conditional cash transfers were an important type of social assistance in Brazil, where a number of existing cash transfer schemes were restructured and unified in the Bolsa Familia programme, which provides an income to poor families if they respect certain conditions such as vaccinating their children and sending them to school. In China, the government scaled up the Dibao programme nationally which provides an additional income to households earning less than a certain threshold. In South Africa, the government has substantially expanded a number of cash transfer programmes, particularly targeting children and the elderly. Finally, India has introduced a cash transfer scheme for pregnant women within the National Food Security Act and it has

\footnotetext{
${ }^{1}$ This is based on the recently revised World Bank's poverty line at $1.90 \mathrm{USD} /$ day at $2011 \mathrm{PPP}$.

${ }^{2}$ The first MDG was to halve the number of people living in extreme poverty by 2015.

${ }^{3}$ Authors' calculation based on data taken from the World Development Indicators (WDI).
} 
expanded the coverage of a number of non-contributory pension schemes, particularly for the disabled, the elderly and widows. Other types of transfers include India's Food Security Act and China's tax-for-fee initiative. The former was introduced in 2013 and provides highly subsidised food to 67 per cent of the population through the Public Distribution System. The latter effectively abolished taxes for rural dwellers, where the majority of the poor live.

Another form of social assistance programmes moved beyond pure income transfer to support broader human, financial or physical asset accumulation. Barrientos (2013) defines these as 'transfers combined with asset accumulation.' These programmes include two important workfare programmes, India's Mahatma Gandhi National Rural Employment Guarantee Act and South Africa's Community Work Programme. Whereas the India's scheme is much broader, both programmes provide work opportunities to the rural population.

The second type of anti-poverty initiative is the expansion of the health sectors. In Brazil, the government has strengthened the Unified Health System (SUS) which provides universal healthcare to all its citizens. China has tried to reverse the trend seen during the 1990s, when a marked retreat of the state from social assistance provision had left many out of the public health care system. The government thus introduced the New Rural Cooperative Medical Scheme with the aim of providing basic health coverage to China's rural population. This has been supplemented by a number of initiatives to provide basic public services to rural migrants to the cities. India has also introduced a programme that increased health care coverage in rural areas through the National Rural Health Mission and through the strengthening and expansion of the Integrated Child Development Services, a programme aimed at tackling child malnutrition in India. South Africa has also discussed the possibility of introducing a universal health care system, but this is still at an embryonic stage.

\section{The macroeconomic environment}

Brazil, India, China and South Africa are the main protagonists of our global poverty reduction story. Table 1 shows the scale of poverty reduction across the four countries using the World Bank poverty line. Of course, as any poverty line, this is somewhat arbitrary and does not necessarily capture the extent of poverty in any given country. However, its comparability across countries and time, makes it a useful indicator to understand trends and the extent of poverty reduction which occurred. ${ }^{4}$ The table clearly shows that extreme poverty ${ }^{5}$ was reduced substantially over the last quarter century in all four countries. This, of course, has much to do with economic growth. Table 2 shows the average annual rates of growth of the GDP in the four countries, including in per capita terms.

\footnotetext{
${ }^{4}$ This is not the place to discuss the limitations of this rather crude way of measuring income poverty. Suffice it to say that, for example, India has recently decided to provide highly subsidised food through the National Food Security Act (2013) to 67 per cent of the population, thus implicitly recognising the inadequacy of a poverty line that identifies only 21 per cent of its population as poor. See Ravallion (2016, ch. 4) for a review of the debates around the poverty line(s).

${ }^{5}$ As per the new international poverty line at $1.90 \$ /$ day.
} 


\section{INSERT TABLES 1 AND 2 HERE}

The GDP figures neatly divide our four cases into two groups. China and India experienced spectacular rates of economic growth (also in per capita terms), while in Brazil and South Africa growth was much more modest, and disappointing in per capita terms. This, and a large and growing body of evidence (World Bank 2014; Ravallion 2016), indicate that economic growth is important for poverty reduction indeed crucial (Rodrik 2008). But it is just part of the story (despite what trickledown economists have argued for a long time): as Barrientos (2013) and others have shown, social programmes and poverty-reduction schemes do matter.

It should be noted that, however important the quantity of economic growth is for poverty reduction, its quality is crucial too. In fact, it is now widely accepted that growth does not automatically trickle-down to the poor and that concentration of income at the top of the socio-economic scale can actually constrain economic growth (IMF 2015a). Studies that have assessed the extent to which growth has been pro-poor in the four countries conclude that Brazil has been very successful at transforming economic growth into poverty reduction. China's performance has also been remarkable. India and South Africa, however, were considerably less effective (Fosu 2011; Ravallion 2011).

The quality of economic growth for poverty reduction is important for at least four reasons. First, the more growth is evenly distributed across regions within any given country, the more robust are the effects in terms of poverty reduction (Chaudhuri and Ravallion 2006). Second, growth will be more effective at reducing poverty if it is concentrated where the majority of the poor live. For example, in a predominantly rural society like China in the 1980s, exceptional growth rates in the primary sector in the wake of the introduction of the household responsibility system reduced poverty spectacularly (Bardhan 2010). On the other hand, the excruciatingly low rate of growth in agriculture in India since the 1990s has significantly reduced the impact of growth on poverty, especially because the manufacturing sector has been unable to create enough jobs (Siddiqui 2015).

Third, the context matters. Generally speaking, high inequality reduces the impact of economic growth on poverty reduction (Ravallion 2016). This is probably the main reason behind the weak performance of South Africa - one of the most unequal countries in the world. However, in Brazil (another highly unequal country) high levels of inequality also meant that the government had significant revenues that could be redistributed (Ravallion 2011). Brazil has a revenue-to-GDP ratio that is comparable to that of the OECD economies (see table 3 below). High human development indicators and relatively low inequality in China meant that the poor were healthy and skilled enough to profit from China's spectacular economic growth (Ranis \& Ramirez 2000). Conversely, low literacy rates and poor health indicators in India constrained both economic growth and poverty reduction (Ravallion 2002). In all cases, moreover, it was crucial that growth occurred in a rather stable macroeconomic environment. Perhaps nowhere is this more evident than in Brazil, where the stabilisation of the currency (the Real) was crucial both for promoting growth and for reducing poverty (Melo, Ng'ethe and Manor 2012). 
Fourth, growth is important per se, but is also important because it results in increased revenues that can be redistributed. Table 3 shows the trend in revenue generation across the four countries (as a percentage of the GDP).

\section{INSERT TABLE 3 ABOUT HERE}

Beside China's exceptional figure, the growth of revenues elsewhere might not look so spectacular. However, in absolute terms, between 2002 and 2012, the resources available to the four governments increased by 171 per cent in Brazil; 197 per cent in South Africa; 300 per cent in India; and 588 per cent in China. ${ }^{6}$

\section{Distributing the proceeds of growth}

The increase in revenues meant that the four governments had substantial resources to spend. Some of these revenues were used to increase allocations both to essential public services like health and education (which particularly benefit the poor) and a range of policy initiatives to tackle poverty and inequality (along with the continuation of policies favouring the middle classes, including labour 'aristocracies' in the formal sector). In this section, we look at patterns in social expenditure across the four countries. Investments in essential public services are crucial for alleviating poverty, fostering poor people's capabilities, promoting economic growth and hence for reducing poverty further.

All four countries increased public spending on health between 20 (Brazil) and 81 per cent (China), as Table 4 shows. Of the four, however, India has an extremely low figure for public heath expenditure. This is matched by India's very high (but declining) figure for out-of-pocket health expenditure (Table 5). It should be remembered that healthcare costs are the single most important reason why people (re)descend into, or remain trapped in, poverty (Krishna 2010). Thus out-of-pocket expenditure is an extremely important indicator as it captures the money that households directly spend for their healthcare and can therefore be used as a proxy for people's health insecurity. The figure for India is almost ten times higher than South Africa's and twice as high China's. The general trend, however, is encouraging.

\section{INSERT TABLE 4 AND 5 ABOUT HERE}

When we turn to education, all countries, barring India, increased expenditure on public education as Table 6 shows. China in particular stands out for its increased commitment to public education, which increased by over 100 per cent, although it still lags behind Brazil and South Africa and remains at a low level. Overall, as Table 7 sets out, the combined expenditure on health and education increased substantially in China, Brazil and South Africa. In India, however, it decreased from an already low level.

\section{INSERT TABLE 6 AND 7 HERE}

\footnotetext{
${ }^{6}$ Authors' calculation on the basis of the data taken from IMF $2015 \mathrm{~b}$.
} 
The next section considers government initiatives to benefit poor people more directly: social assistance programmes and poverty reduction schemes. These are immensely important because despite the drastic reduction of poverty witnessed in recent years, a sizable part of the population in the four countries still live on the edge of poverty (see Figure 1). As figure 1 shows, nearly 80 per cent of the population of India, more than 50 per cent of South Africa's, almost 40 per cent China's, and about 17 per cent of Brazil's still live in poverty (below 3.10 USD/day) or extreme poverty (below $1.90 \mathrm{USD} /$ day). In this context, it is clear that the role of the state is crucial for providing safety nets and support systems not only aimed at lifting people out of poverty, but also at preventing them falling back into it. Globally, 11 per cent of today's poor are people who descended into poverty during their lifetime (Krishna 2010).

Figure 1 - Percentage of the population living in poverty (3.10 USD/day) and extreme poverty (1.90 USD/day).

\section{FIGURE 1 HERE}

Source: WDI. All data are from 2011 except for China (2010).

Policy initiatives are important for reducing poverty and (less often) inequality (Barrientos 2011). India's Mahatma Gandhi National Rural Employment Guarantee Act (MGNREGA), for example, is credited with an overall poverty reduction of 32 per cent and for preventing 14 million people from falling into poverty (Desai, Vashishtha and Joshi 2015). Brazil's Bolsa Familia alone was responsible for 21 per cent of the fall in inequality (Soares, Ribas, Osorio 2010). South Africa's cash transfer programmes have also been important for poverty reduction (Barrientos and DeJong 2006).

Table 8 below shows social assistance expenditure trends across the four countries. This is a rough indicator of spending on anti-poverty initiatives, social safety nets and other forms of support to the poor. However, the data is not strictly comparable across countries. To the best of our knowledge, there is no reliable data available on social protection expenditure for all our four countries across time. Hence it is necessary to take data from different sources, which impedes comparability. It should be noted that even data taken from a single source like the World Bank or the ILO are difficult to compare and rely on. ${ }^{7}$ Even data taken from national budgets is not comparable as each country defines social protection/assistance differently. But if we consider the broad patterns that emerge, it is possible to draw cautious conclusions about trends

\footnotetext{
${ }^{7}$ The World Bank's ASPIRE database has data for a single year for the four countries; but the dataset's reliability is questionable. For example, the figure for India for total social expenditure is 0.7 per cent of GDP in 2014. However, three programmes alone (the MGNREGA, the Midday Meal Scheme and the Integrated Child Development Services) account for more than that amount. The ILO's SECSOC database does not include data for India and includes health expenditure in South Africa and pension expenditure in Brazil (which is a highly regressive form of social security in Brazil, as it benefits the better offs). IFPRI's SPEED figures are highly questionable too. See also Barrientos (2013, p. 168 and ff. for a discussion of these issues).
} 
over time: thus Table 8 shows that all four countries increased social expenditure, however defined.

\section{INSERT TABLE 8 ABOUT HERE}

Overall, it is safe to conclude that all four countries were able to distribute (at least partially) the fruits of economic growth, to reduce income poverty and to prevent some non-poor from descending back into poverty. The policy efforts involved differed by country. The Chinese government has introduced fewer programmes that explicitly seek - as their main aim -- to reduce poverty. But some of its initiatives which for the most part focus on related goals (for example, ending taxation on rural incomes, and the effort to address needs in less developed western provinces) have had a poverty-reducing impact. Moreover, China's increasing commitment to essential public services - expenditure on health and education increased by over 80 per cent as a proportion of GDP between 1999 and 2012 - indicates that a significant number of poor people benefited at least partially from China's growth story.

In India, some poverty programmes have been weakened by poor formulation and/or implementation. This reminds us that while increased social expenditure often reduces poverty, this does not always occur. But at least some of them - the MGNREGA and the Midday Meal scheme, above all - had a substantial impact on the welfare of the poor. Furthermore, the evidence on household incomes set out in the next section from an authoritative survey by India's National Council of Applied Economic Research (NCAER) and the University of Maryland plainly indicates that its bundle of poverty initiatives have had a significant effect on reducing poverty. India's commitments to essential public services, however, remain low - and declining - and they disproportionately affect the poor, who cannot afford decent-quality private alternatives. Indeed, the neglect of public services has a long history in India. Kapur and Nangia (2015) convincingly argue that when India's policy-makers are faced with the choice of investing limited state resources in either public services or povertyreduction programmes, they tend to choose the latter. This might have something to do with the prominent role of patronage in South Asia (Piliavsky 2014) and with an increasingly competitive party system, which provides incentives to politicians to distribute tangible and immediate goods to the poor, rather than investing in longerterm development through public services. Despite this, many Indian politicians at national and state levels have increasingly stressed 'post-clientelist' initiatives which are largely protected from those involved in patronage distribution - because their developmental impact and the political pay-offs that ensue are greater (Manor 2013 and 2016).

In South Africa, the expansion of cash transfer programmes has benefited the poor significantly as has the increased commitment to public education and health. Jeremy Seekings (2011) attributes the decline of income poverty primarily to the expansion of social assistance and notes that expenditure on poverty reduction policies increased sharply, from about 2 per cent of GDP in 2000 to 3.5 per cent, in 2006. Hence, in South Africa too, the poor at least partially benefited from distributive policies.

The evidence from Brazil is more straightforward. Of the four cases, it is clearest that its various initiatives have patently had a potent redistributive effect, and have 
reduced income poverty and inequality. This is largely the result of a long-term commitment by successive Brazilian governments to reduce poverty and inequality (Melo, Ng'ethe and Manor 2012) and to public opinion that largely supports higher spending on both poverty reduction policies and public services (Hall 2006; see also Pereira and Bartholini in this special issue).

\section{Reaching the poorest}

It is well understood that it is exceedingly difficult for poverty initiatives to reach the poorest of the poor. Over the last half-century, many programmes across the developing world which have benefited some - or many - poor people have had little impact on the most destitute. They are extremely vulnerable, largely bereft of capabilities, and locked into invidious bonds of dependency upon prosperous groups. They usually suffer extreme discrimination and exclusion, which are often sociocultural in origin. They stand at what Milton called "the utmost edge of hazard".

The literature has highlighted how the poorest are sometimes left out of development programmes by design because they lack the 'potential' to escape poverty (Halder \& Mosley 2004). At other times they are 'invisible' to the state because, for example, they do not have an address, or because they live in dangerous areas where surveyors tasked with the identification of beneficiaries are not willing to venture (Carr-Hill, 2013). A further reason is that the poorest of the poor suffer from a severe shortage of capabilities (especially education) that make access to social protection programmes even more difficult. In other words, reaching the poorest of the poor requires targeting this group specifically and with specific tools that countries and donors often do not have the capacity (or willingness) to adopt (Datta 2004).

It is difficult to say with certainty to what extent social programmes in Brazil, India, China and South Africa reached the poorest, partly because of a lack of impact studies focusing on the most destitute sections of populations and partly because many social programmes target specific sections of the poor (the elderly, children, women, rural unemployed etc.) which may or may not be (or include many of) the poorest of the poor.

We can, however, get at least a rough idea of the extent to which the neediest were reached. In China, where the evidence is limited, some of the poorest will surely have benefited - at least modestly - from policies that mainly reached other, less destitute sections of 'the poor'. For example, when taxation on rural incomes was ended in 2006, the plight of the poorest villagers was eased to at least a limited extent. Rural taxes in China were highly regressive. According to Li and Sicular (2014), in 1995 the tax rate of the poorest decile was five times higher than that of the highest decile. Therefore, the abolition of taxes and fees for rural dwellers disproportionately benefited the poorest. As a result, the scheme is credited with reducing inequalities within villages (Alm and Liu 2014). The marked increase of subsidies for farmers (22.5 per cent a year between 2003 and 2009), on the other hand, resulted in a rather uneven distribution - the poorer the farmer, the lower the subsidy they received. However, evidence shows that all farmers - including the poorest - were able to get this form of support from the government (Lin \& Wong, 2012). 
On a less positive note, the massive migration of Chinese rural dwellers into urban centres in search of employment entailed not just entrepreneurial decisions by people who were somewhat poor, but also desperate actions by those who were - in the evocative words of a South African poverty campaigner - "well under". ${ }^{8}$ In China's cities, work for the poorest was often very difficult to obtain, so that their prospects did not necessarily improve; and, second, migrant workers could not - and, by and large, still cannot - access basic public services like healthcare and education, because of the persistence of the Hukou system. ${ }^{9}$ Policies recently introduced to ameliorate the living conditions of migrant workers - many of whom who can be safely classified as among the most vulnerable in China - did not have a significant impact, as the great majority of them are still not covered by social security schemes (Cook \& Kabeer 2011, ch. 6).

Other policies in China similarly failed to reach the poorest. For example, the cash transfer programme for the urban poor, Dibao, reached just 39 per cent of the urban poor (Wang 2007; see also Golan, Sicular and Umapathi 2017), whereas its ruralfocussed counterpart had only a limited impact on poverty rates (Golan, Sicular \& Umapathi 2015). Also the introduction of the Labour Contract Law in 2008 disproportionately benefited urban rather than rural migrants (Cheng, Smyth \& Guo 2015) and more educated rather than less educated workers (Gallagher, Giles, Park, \& Wang 2015).

The evidence from South Africa is again rather limited, but some non-trivial gains appear to have been made. It is safe to assume that the programme to provide employment on government-funded projects in rural areas where poverty is most acute in that country, the Community Work Programme - modelled on the larger Indian public works initiative - gave opportunities to some of the poorest (Andersson and Alexander, forthcoming). But the scale of that initiative was limited and, despite a promising start, the programme is now affected by a number of implementation faults that limit its impact, including on the poorest (Meth 2011).

The introduction and expansion of social grants for vulnerable groups appears to have had a much greater impact on the most destitute (urban and rural), so some significant headway was made (Leibbrandt, Woolard, McEwen, \& Koep 2010). Jeremy Seekings (2011, p37) notes:

these social assistance programs had a major effect on poverty because they were well targeted to the poor. ...Almost 60 percent... went to households in the poorest quintile. About 30 percent was shared between households in the second and third income quintiles.

In Brazil, efforts to reach the poor, and the poorest, were much more long-standing, substantial, comprehensive and effectively implemented than in the other three countries. This has much to do with the excellent targeting of Brazil's flagship conditional cash transfer programme, Bolsa Familia. According to a World Bank Study (Lindert, Linder, Hobbs \& de la Brière, 2007, 46) the poorest 25 per cent of the population receives $80 \%$ of all benefits and inclusion of non-poor among the

\footnotetext{
8 Interview by James Manor with an informant in Durban, 26 February 1998.

${ }^{9}$ The Hukou system formally identifies a person as a resident of an area. That person will be allowed to access public services only in the area where he/she resides.
} 
beneficiaries is virtually non-existent (Soares et al. 2010). There is also evidence that the increased commitment of the government to universal public healthcare has resulted in increased coverage. According to a recent study, 90 per cent of Brazilians have now access to public health care (Gragnolati, Lindelow and Cuttolenc 2013).

This leaves India where many of the poverty-reduction initiatives were afflicted by design faults and/or problems during implementation. However, the picture is not entirely grim. The poorest made very substantial gains made under the largest Indian programme, the Mahatma Gandhi National Rural Employment Guarantee Act (MGNREGA). Consider, by way of illustration, the following figures on the social groups which obtained employment from it. Many of the poorest rural dwellers (and roughly two-thirds of Indians reside in rural areas) can be found in two such groups: the Scheduled Castes (ex-untouchables or Dalits) and the Scheduled Tribes (adivasis).

\section{INSERT TABLE 9 ABOUT HERE}

These marginalised groups, and thus significant numbers of India's poorest, gained disproportionately from this huge programme. This provides much of the explanation for the important, authoritative finding of the NCAER/University of Maryland study that while per capita household incomes among high caste Hindus (the most prosperous group) had increased by 4.6\% per annum between 2004-05 and 2011-12, significantly larger gains were made by all other categories. 'Other Backward Castes' (the lower-middle stratum in the traditional caste hierarchy) saw per capita incomes increase by $7.3 \%$; Scheduled Castes by $7.8 \%$; Scheduled Tribes by $5.7 \%$; and Muslims by $5.4 \%{ }^{10}$ The last three of those groups include many of India's poorest people. (That same study found - rather surprisingly -- that in percentage terms, household incomes in rural areas had increased more between 2004 and 2012 than had urban household incomes.)

So some of the poorest were reached by government initiatives in China, a larger proportion of them was reached in South Africa, and still larger proportions were reached in Brazil and India. These are impressive achievements, but we must turn to a further question, to which the answers are less encouraging.

\section{Was inequality reduced?}

If reaching the poorest is extremely difficult, reducing inequality - even when the income poverty of many is eased - is even harder. This is apparent from evidence on the countries that we have analysed.

For a telling example, consider the comments just above on India. Poorer groups benefited disproportionately from the MGNREGA, and the NCAER/University of Maryland findings indicate that all poorer groups saw greater increases in their household incomes than did the richest. But this does not necessarily imply that income inequality shrank. The increases in those household incomes are reported in percentage terms. The most prosperous group may only have seen an annual increase of $4.6 \%$ in their household incomes - less, sometimes far less than other poorer

10 Ibid., and The Hindu, 30 March and 5 April 2014. 
groups. But their incomes at the start were considerably greater than those of the three groups that contain many of the poorest, so in absolute terms, an increase of $4.6 \%$ still enabled them to gain more than those poorer groups gained, despite the differences in percentage terms. So inequalities in the funds available to these groups appear to have widened, despite the greater gains of the poor in percentage terms.

Data shows that, among our four cases, only Brazil succeeded at reducing income inequalities. Table 10 shows income inequality trends as measured by the Gini coefficient. Of course, this is a rather crude measure of inequality. The Gini coefficient is very sensitive to changes in income in the middle strata, and tends to underestimate the changes at the extremes. In highly unequal countries like Brazil and South Africa, this is a serious limitation. It also does not take into account demographic changes: in a country like India that is experiencing a very rapid increase in the working age population, or in a country like China that is aging fast, this again constitutes a rather serious problem. The Gini coefficient is even more imperfect when calculated for countries with a large informal economy (which is the case in all of our four cases). Furthermore, since the Gini coefficient is a measure of income inequality, it does not capture other forms of inequality: regional, educational, urban-rural or socio-cultural, for example. Lastly, while most countries use income as the key variable for measuring inequality, some (including India) use consumption expenditure, which tends to artificially lower the Gini coefficient (Desai et al. 2010). However, despite such limitations, the Gini coefficient does have the clear advantage of being available for most countries and across time.

\section{INSERT TABLE 10 ABOUT HERE}

The table above shows that inequality has increased in all four countries barring Brazil. It has been widely acknowledged that in recent years, income inequality there has been reduced as a result of longer-standing efforts to tackle poverty and inequality by successive governments since 1992. They were headed by three presidents from two different progressive parties: Fernando Henrique Cardoso of the PSDB or Brazilian Social Democratic Party, 1992-200, and from the PT or Workers' Party, Lula da Silva, 2000-08, and Dilma Rouseff, 2008-16. (On Cardoso, see Melo, Ng'ethe and Manor, 2012, ch. 4). Multi-party politics mattered in India as well, but strong efforts to tackle poverty and inequality only began there in 2004 - much later than in Brazil - when the United Progressive Alliance led by the Congress Party took power. Multi-party politics scarcely counted in South Africa where the African National Congress was largely dominant until mid-2016, and it was absent in China. The gains made in Brazil may now be reversed since Dilma Rouseff was forced to resign in 2016 amid a corruption scandal and a severe economic downturn - to be succeeded by leaders who have begun to undermine poverty programmes.

The last column in the table also shows how different India's figure looks when income is used as the basis for the calculation of the Gini (as opposed to consumption expenditure, as in the third column). If we use consumption expenditure, India is a moderately unequal country; if we use income, it is a highly unequal country, actually more unequal than Brazil today. Other estimates of the income-based Gini for India reach similar conclusions (IMF 2015b). 
A rather similar picture emerges from Credit Suisse's Wealth Report (2015), that provides the Gini coefficient of wealth and is thus a measure of how (un)equally wealth is distributed in any given country. Table 11 provides the four countries' figures. When looking at wealth, not even Brazil has succeeded in reducing wealth inequality, which is even more difficult to do than reducing income inequality.

\section{INSERT TABLE 11 ABOUT HERE}

Finally, figures 2 and 3 show how the income (consumption, in the case of India) of the top and bottom deciles of the spectrum has changed since the early 1990s. Two points are particularly worth noting. First, the reduction of inequalities in Brazil is due both to an increase of the share of income of the poorest 10 per cent of the population - which is still very low at less than 1 per cent of the country's total income - and to a decrease of the share of the richest, which declined from 48.44 per cent in 1993 to 41.89 in 2010. This is a remarkable achievement, as pursuing a set of policies that negatively affect the richest is something that most countries in the world have found politically infeasible. China and South Africa, however, also succeeded (in the 2000s) at reducing the share of income of the richest. Second, China has seen a drastic drop in the income share of the poorest since the 1990s. A drop can be seen in India and South Africa too, but is much less dramatic. As argued above, the poorest have indeed been benefiting from social protection policies implemented by their governments; but this has been barely enough to mitigate their poverty and certainly not enough to ease their plight at the bottom of the socio-economic ladder.

Figure 2 - Income share of the bottom 10\% 1993-2010/11

\section{FIGURE 2 HERE}

Figure 3 - Income share of the top 10\% 1993-2010/11

\section{FIGURE 3 HERE}

Source: World Bank's Poverty and Equity Database.

So in summation, some of the proceeds of growth were distributed and income poverty was reduced in all four of our countries: Brazil, India, China and South Africa. The vexing difficulties of reaching the poorest were addressed to some degree in China and to a greater extent in the other three countries. But the excruciatingly difficult task of reducing inequality was successfully tackled only in Brazil.

\section{Beyond incomes: further dimensions of poverty and inequality}

The discussion in the previous sections focused on income poverty (and inequality). But in this project, we have used a broad definition of 'poverty'. It entails not just a severe shortage of incomes, assets and funds, but also a severe shortage of opportunities, liberties and capabilities. In this section we look at how some basic human development indicators (mainly related to health and education) changed in recent years in the four countries. In the final section we will discuss an especially 
important capability - 'political capacity' - a lack of which we consider to be an important dimension of people's poverty.

Table 12 provides a crude indicator of health in the four countries by looking at life expectancy. Brazil and China's figures are not yet on par with OECD members' (80.1), but they are not far off it. India's figure is on par with that of South Asia (68.1), but lower than neighbouring and much poorer countries like Bangladesh (71.6) and even Nepal (69.6). India's figure in 2014 is worse than China's in 1990 (69), but as the table shows, it is making relatively rapid progress. South Africa's life expectancy is lower than that of the poorest area in the world, Sub-Saharan Africa (58.6). This has much to do with the HIV-AIDS epidemics of the 1990s, from which South Africa has not fully recovered yet (most Sub-Saharan African countries were affected too). Life expectancy in South Africa has actually dropped from 62.1 in 1990 and it is now slowly recovering.

\section{INSERT TABLE 12 ABOUT HERE}

Life expectancy is strongly influenced by high mortality rates among children. Table 13 provides data for infant (below 1 year of age) and child (below 5) mortality rates. As the table shows, all countries made significant progress, although the figures from India and South Africa are still alarming. It is also significant that the rate of reduction of both the infant and child mortality rates is slower than in China and in Brazil, despite the fact that India and South Africa started from a rather low base. High infant and child mortality rates are to a significant extent due to poor public commitment to the welfare of the children as shown in Tables 14 and 15 which provide immunisation and malnutrition (stunting) rates, respectively.

\section{INSERT TABLE 13-15 HERE}

Stunting is the most reliable indicator of a child's well-being. Brazil and China almost halved their already relatively low figures for children under five who are stunted, whereas India and South Africa lag behind. In particular, India's figure is higher than that of most Sub-Saharan African countries. Children who suffer from malnutrition in the first two years of their lives are irremediably stunted, both mentally and physically (Gragnolati, Bredenkamp, Shekar, Das Gupta \& Lee 2006). Their brains do not develop fully, so they are left - permanently - with avoidably low mental capacity. Physical stunting makes them weaker and more vulnerable to illnesses, which of course undermines their capacity to sustain their livelihoods. So in both ways, malnutrition limits the resources both of the poor people who suffer from it, and of the nation in which they live. It compounds the problems of inequality which poor people face.

The next tables turn to education indicators. Table 16 shows literacy trends across the four countries. It shows that India is the only country that lags behind. However, the situation is improving rapidly. Two bits of particularly good news are, first, the solid achievements in India in terms of net enrolment rates to primary school - which improved from 84.13 per cent in 2000 to 94.98 per cent in 2013. Second, the gender gap in enrolment rates has been substantially reduced. 91.77 and 98.57 per cent of 
female and male children, respectively, are enrolled in schools today. The completion rate is also high at 96 per cent (with no gender gap) (WDI). This certainly has much to do with the universalisation of the Midday Meal scheme and the enactment of the Right to Education Act in recent years. Enrolment rates are of course not an indication of the quality of education, which is an extremely serious problem in India,

particularly in rural areas (ASER 2015).

\section{INSERT TABLE 16 ABOUT HERE}

Finally, Table 17 shows maternal mortality rates which provide a crude indication of public commitment to the welfare of women. Here the story is similar to other development indicators. India is the outlier as skilled staff attend only slightly more than half of the births, which is reflected in the still very high rate of maternal deaths. In South Africa, the extremely high rate is due to the HIV epidemic, which had contributed to bring the rate to 400 per 100,000 live births by 2005. Both India and South Africa missed the maternal-related Millennium Development Goals (Goal 5).

\section{INSERT TABLE 17 ABOUT HERE}

\section{Political Capacity}

We conclude our discussion with another especially important capability: 'political capacity'. It consists of four elements which for many poor people are in very short supply: their political awareness (their understanding of local power dynamics and political processes); their confidence as political actors in those processes and in the public sphere; their political skills; and their political connections to other poor people and to allies among the non-poor.

If a government initiative enables poor people to strengthen their political capacity, by drawing them into the public sphere as proactive participants, then it has two effects -as a poverty-reducing end in itself, and as a means to enable further poverty-reducing gains. A severe lack of political capacity is one disabling dimension of poor people's 'poverty' - many poor people are poor partly because they are bereft of political capacity. So if their political capacity can be enhanced, that in itself erodes one aspect of their poverty - as an end in itself. But when they acquire greater political capacity, they also become better able to engage with grassroots political dynamics in contestation and/or collaboration. That may enable them to exert at least some influence, and perhaps to make and then to defend material gains. That, in turn, reduces (i) their dependence on elites, (ii) their poverty (when seen in material terms), and (iii) invidious local inequalities. So the enhancement of political capacity can also serve as a means to those ends.

Some of the poverty initiatives that we have studied in these four countries have had this kind of enabling impact, but there are important variations. Several policies and processes that have been introduced in Brazil since the mid-1990s have had an effect here. The exercise in participatory budgeting which originated in Porto Alegre is one 
well known example (Santos 1998). Only one of the Indian initiatives that we have analysed had a similar impact, but it was sufficiently massive that it made an important difference. It thus deserves attention here - partly to explain how political capacity might be enhanced, and partly because responses to it by Chinese and South African policy makers are revealing.

The Indian programme in question is its rural employment guarantee scheme (the MGNREGA). It was intended to provide poor rural dwellers with much needed wages, but it did not merely entail the disbursal of money to the poor, as cash transfers do. Such transfers certainly qualify as constructive poverty programmes, and they have had a substantial impact (as we have seen above) in Brazil and South Africa. But the beneficiaries in such programmes are largely passive recipients. The MGNREGA was different. It gave every poor rural household the right to demand and receive up to 100 days employment per year on construction sites. In other words, poor villagers were enabled and incentivised to seek work proactively. The aim was to draw them into the public sphere: when they demanded work, when they performed labour on projects, and when they collected wages from their bank accounts through which they were paid to combat pilfering. ${ }^{11}$

The architects of the MGNREGA knew that attempts would be made by unscrupulous actors at and near the local level to steal funds from the programme and from workers' wages. They therefore introduced powerful transparency mechanisms to impede such attempts, and to make them visible to poor villagers. They knew that this would inspire discontent among the poor, but they welcomed that because discontent would spur poor people to yet more proactive engagement in the public sphere. In other words, one key aim of the MGNREGA was to enhance poor people's political awareness, confidence, skills and connections - their political capacity. The programme tackled poverty in two ways: by giving the poor opportunities to earn much needed wages, and by strengthening their capabilities. Massive numbers of poor people responded, and the MGNREGA had a substantial impact on both dimensions of their poverty.

After the programme had achieved considerable success in its early years, a team of government analysts from China visited India for talks about development strategies. It became apparent as discussions proceeded that the Chinese were only interested in one Indian programme, the MGNREGA. But they made it clear that if China developed something similar, it would not include the crucially important demanddriven elements of the Indian programme, or the strong transparency mechanisms that are key features of it. The delegates from Beijing plainly stated that a Chinese counterpart would be a much more top-down operation dominated by agents of the party-state. They preferred to avoid building political capacity. ${ }^{12}$

\footnotetext{
${ }^{11}$ It had an especially strong impact on poor village women - who, in many parts of India, seldom left their houses before the MGNREGA. They performed a substantial proportion of the work under that programme - many millions of person-days -- which drew them into the public sphere where they developed ties to other poor women. It also paid them wages in their own names which often gave them a degree of material autonomy within their households. One team of field researchers found that domestic violence had decreased after women had worked under the MGNREGA. These issues are discussed in much greater detail in Jenkins and Manor (2017).

12 These comments are based on interviews by James Manor with two Indian officials who took part in the talks, New Delhi, 7 August 2012.
} 
After the MGNREGA had shown early promise, the South African government decided to introduce an adaptation of it in rural areas where poverty is more acute than in urban areas, and where jobs are extremely scarce. But their programme differed from the Indian version in one important respect. The key implementing agencies at the grassroots in India are elected local councils which provide arenas for political contestation and the strengthening of poor people's political capacity. In South Africa, however, local councils created in 2000 have been crippled by excessive top-down bureaucratic control and technocratic overload, as a result of elite distrust of the rustics elected to them (see Siddle and Koelble 2012). So they cannot play such a role there. This forced policy makers to turn to civil society organisations, which are well versed in participatory methods, as the main promoters of the programme. They have done good work, but this arrangement impedes the development of poor people's political capacity on a scale seen in India's MGNREGA or in some Brazilian initiatives. ${ }^{13}$

To reiterate: a severe shortage of political capacity is an important dimension of poor people's poverty. In China, that dimension has been left unaddressed because political leaders who influence poverty initiatives prefer to avoid that. In the same vein, it is notable that an early Chinese experiment with elections of officials at the township level - the lowest level at which executive power is exercised - has been abandoned. In South Africa, the weakness of elected local councils has forced policy makers to turn to civil society organisations which have responded well but which cannot provide arenas for local democratic contestation of the kind that are found in India (and Brazil). So the impact on poor people's political capacity is and will remain less strong there.

\section{Conclusion}

Since 2002 or so, governments in Brazil, India, China and South Africa have adopted new initiatives - or intensified older efforts - to pursue three goals: reducing income poverty; reaching the poorest of the poor; and reducing income inequality. The outcomes have varied from country to country, and from programme to programme. Significant headway has been made in all four countries in tackling the first and easiest of these challenges, and (more remarkably) the second and more daunting problem. The third, reducing income inequality, is far more difficult. Only Brazil has succeeded there.

This analysis has also looked beyond income poverty and inequality by considering another important set of problems which poor people face: a severe lack of opportunities, liberties and capabilities. We have examined efforts by these governments to address these things - by improving human development indicators linked to their opportunities and capabilities (nutrition, health care, literacy, etc.), and by enhancing their 'political capacity' -- so that they are better able, proactively, to pursue and defend their interests.

\footnotetext{
13 This paragraph draws on James Manor's discussions of the workings of the MGNREGA with South African officials as they developed their plans for a rural employment programme.
} 
Somewhat different strategies, different types of government initiatives, have been used in the four countries. Some have been more effective than others, but all have had some impact. The discussion of these variations indicates the breadth of the menu of feasible, promising options available to policy makers who might wish to tackle poverty and inequality.

\section{References}

Alm, J., \& Liu, Y. (2014). China's tax-for-fee reform and village inequality. Oxford Development Studies, 42(1), 38-64.

Andersson, G. \& Alexander, P. (forthcoming). The Community Work Programme: Potential and Disappointment.

ASER (2015). Annual Status of Education Report 2014. New Delhi: ASER Centre.

Bardhan, Pranab, (2010). Awakening Giants, Feet of Clay - Assessing the Economic Rise of China and India, Princeton: Princeton University Press.

Barrientos, A. (2011). Social protection and poverty. International Journal of Social Welfare, 20(3), 240-249.

Barrientos, A. (2013). Social assistance in developing countries. Cambridge: Cambridge University Press.

Barrientos, A., \& DeJong, J. (2006). Reducing child poverty with cash transfers: A sure thing?. Development policy review, 24(5), 537-552.

Castro, J. A. D., Ribeiro, J. A. C., Chaves, J. V., \& Duarte, B. C. (2012). Gasto Social Federal: prioridade macroeconômica no período 1995-2010. Brasilia: IPEA.

Carr-Hill, R. (2013). Missing millions and measuring development progress. World Development, 46, 30-44.

Chaudhuri, S., \& Ravallion, M. (2006). Partially awakened giants: Uneven growth in China and India (Working Paper S4069). Washington DC: The World Bank.

Cheng, Z., Smyth, R., \& Guo, F. (2015). The impact of China's new Labour Contract Law on socioeconomic outcomes for migrant and urban workers. human relations, 68(3), 329-352.

Cook, S., \& Kabeer, N. (Eds.). (2011). Social protection as development policy: Asian perspectives. Oxon: Routledge.

Credit Suisse (2015). Global Wealth report 2015. Zurich: Credit Suisse.

Datta, D. (2004). Microcredit in rural Bangladesh: Is it reaching the poorest?. Journal of Microfinance/ESR Review, 6(1), 55-82. 
Desai, S., Vashishtha, P. and Joshi, O. (2015). Mahatma Gandhi National Rural Employment Guarantee Act: A Catalyst for Rural Transformation. New Delhi: National Council of Applied Economic Research.

Fosu, A. (2011). Growth, inequality, and poverty reduction in developing countries: recent global evidence. Brooks World Poverty Institute Working Paper, (147). Manchester: University of Manchester.

Gallagher, M., Giles, J., Park, A., Wang, M. (2015), China's 2008 Labor Contract Law: Implementation and implications for China's workers, Human Relations, Vol 68, Issue 2, pp. $197-235$.

Golan, J., Sicular, T., \& Umapathi, N. (2015). Unconditional Cash Transfers in China. Policy Research Working Paper Series. Washington DC: The World Bank.

Golan, J., Sicular, T., \& Umapathi, N. (2017). Unconditional Cash Transfers in China: Who Benefits from the Rural Minimum Living Standard Guarantee (Dibao) Program?. World Development (online preview).

Gragnolati, M., Bredenkamp, C., Gupta, M. D., Lee, Y. K., \& Shekar, M. (2006). ICDS and persistent undernutrition: Strategies to enhance the impact. Economic and Political Weekly, 1193-1201.

Gragnolati, M., Lindelow, M., \& Couttolenc, B. (2013). Twenty years of health system reform in Brazil: an assessment of the sistema unico de saude. Washington DC: World Bank Publications.

Hall, A. (2006). From Fome Zero to Bolsa Família: social policies and poverty alleviation under Lula. Journal of Latin American Studies, 38(04), 689-709.

Halder, S. R., \& Mosley, P. (2004). Working with the ultra- poor: learning from BRAC experiences. Journal of International Development, 16(3), 387-406.

IMF (2015a). Dabla-Norris, M. E., Kochhar, M. K., Suphaphiphat, M. N., Ricka, M. F., \& Tsounta, E. Causes and consequences of income inequality: a global perspective. Washington DC: International Monetary Fund.

IMF (2015b). World Economic Outlook. Washington DC: International Monetary Fund.

Kapur, D., \& Nangia, P. (2015). Social Protection in India: A Welfare State Sans Public Goods?. India Review, 14(1), 73-90.

Krishna, A. (2010). One illness away: Why people become poor and how they escape poverty. Oxford: Oxford University Press.

Jenkins, R. \& Manor, J. (2017). Politics and Right to Work - India's Mahatma Gandhi National Rural Employment Guarantee Act. London and New York: Hurst \& Co./Oxford University Press. 
Leibbrandt, M., Woolard, I., McEwen, H., \& Koep, C. (2010). Employment and inequality outcomes in South Africa. Cape Town: SALDRU, University of Cape Town.

Li, S., \& Sicular, T. (2014). The distribution of household income in China: inequality, poverty and policies. The China Quarterly, 217, 1-41.

Lin, W., \& Wong, C. (2012). Are Beijing's Equalization Policies Reaching the Poor? An Analysis of Direct Subsidies Under the "Three Rurals"(Sannong). China Journal, (67), 23-46.

Lindert, K., Linder, A., Hobbs, J., \& De la Brière, B. (2007). The nuts and bolts of Brazil's Bolsa Família Program: implementing conditional cash transfers in a decentralized context. Washington DC: The World Bank.

Manor, J. (2013). Post-clientelist initiatives in K. Stokke and O. Tornquist (eds.) democratization in the global south: the importance of transformative politics. London: Palgrave, 243-53.

Manor, J. (2016). India's States: The Struggle to Govern in Studies in Indian Politics 4 (1): 8-21.

Melo, M., Ng'ethe, N., \& Manor, J. (2012). Against the odds: Politicians, institutions and the struggle against poverty. London and New York: Hurst \& Co/Columbia University Press.

Meth, C. (2011). Employer of Last Resort? South Africa's Expanded Public Works Programme (EPWP). SALDRU Working Paper Series, 58. Cape Town: SALDRU, University of Cape Town.

Piliavsky, A. (Ed.). (2014). Patronage as politics in South Asia. Cambridge: Cambridge University Press.

Ranis, G., Stewart, F., \& Ramirez, A. (2000). Economic growth and human development. World development, 28(2), 197-219.

Ravallion, M., \& Datt, G. (2002). Why has economic growth been more pro-poor in some states of India than others?. Journal of development economics, 68(2), 381-400.

Ravallion, M. (2011). A comparative perspective on poverty reduction in Brazil, China, and India. The World Bank Research Observer, 26(1), 71-104.

Ravallion, M. (2016). The Economics of Poverty. History, Measurement. Policy. New York: Oxford University press

Rodrik, D. (2008). One economics, many recipes: globalization, institutions, and economic growth. Princeton: Princeton University Press. 
Santos, Boaventrua de Sousa. 1998. "Participatory Budgeting in Porto Alegre:

Toward a Redistributive Democracy", Politics and Society. 26 (4): 461-510.

Seekings, J. (2011). Poverty and inequality in South Africa, 1994-2007. In I Shapiro \& K. Tebeau (eds.), After Apartheid: Reinventing South Africa?. Charlottesville and London: University of Virginia Press.

Siddle, A. and Koelble, T. (2012). The Failure of Decentralisation in South African Local Government: Complexity and Unanticipated Consequences. Cape Town: UCT Press.

Siddiqui, Kalim (2015). Agrarian Crisis and Transformation in India. Journal of Economics and Political Economy, 2 (1). pp. 3-22.

Soares, F. V., Ribas, R. P., \& Osório, R. G. (2010). Evaluating the impact of Brazil's Bolsa Familia: Cash transfer programs in comparative perspective. Latin American Research Review, 45(2), 173-190.

Wang, M. (2007). Emerging urban poverty and effects of the Dibao program on alleviating poverty in China. China \& World Economy, 15(2), 74-88.

World Bank (2014). Prosperity for all: Ending Extreme Poverty. Washington, DC: The World Bank. 
Table 1 - Poverty reduction in Brazil, India, China and South Africa 1990-2012

\begin{tabular}{|l|l|l|l|l|}
\hline & $\begin{array}{l}\text { \% pop below } \\
1.90 \$ / \text { day } \\
1990 \mathrm{~s}\end{array}$ & $\begin{array}{l}\% \text { pop below } \\
1.90 \$ / \text { day } \\
2010 \mathrm{~s}\end{array}$ & $\begin{array}{l}\text { Percentage } \\
\text { reduction 1990s- } \\
2010 \mathrm{~s}\end{array}$ & $\begin{array}{l}\text { Percentage } \\
\text { reduction 2002- } \\
10 \mathrm{~s}\end{array}$ \\
\hline Brazil & 20.56 & 4.59 & $77.68 \%$ & $62.71 \%$ \\
\hline China & 66.58 & 11.18 & $83.21 \%$ & $65.01 \%$ \\
\hline India & 46.06 & 21.25 & $53.86 \%$ & $44.66 \%$ \\
\hline $\begin{array}{l}\text { South } \\
\text { Africa }\end{array}$ & 31.91 & 16.56 & $48.10 \%$ & $52.95 \%$ \\
\hline
\end{tabular}

Source: World Development Indicators (WDI). Brazil's data are from 1990 and 2012; China: 1990 and 2010: India: 1993 and 2011; South Africa: 1993 and 2011. 
Table 2 - GDP and per capita GDP growth 1990-2014

\begin{tabular}{|l|l|l|l|l|}
\hline & $\begin{array}{l}\text { Average } \\
\text { annual GDP } \\
\text { Growth 1990- } \\
2014\end{array}$ & $\begin{array}{l}\text { Average annual } \\
\text { GDP growth } \\
2002-14\end{array}$ & $\begin{array}{l}\text { Average per } \\
\text { capita GDP } \\
\text { growth 1990- } \\
2014\end{array}$ & $\begin{array}{l}\text { Average per } \\
\text { capita GDP } \\
\text { growth 2002- } \\
14\end{array}$ \\
\hline Brazil & 2.77 & 3.43 & 1.41 & 2.29 \\
\hline China & 9.84 & 9.93 & 8.97 & 9.33 \\
\hline India & 6.51 & 7.42 & 4.75 & 5.86 \\
\hline South Africa & 2.48 & 3.18 & 0.66 & 1.72 \\
\hline
\end{tabular}

Source: Authors' calculation based on WDI . 
Table 3 - Revenue growth as percentage of GDP

\begin{tabular}{|l|l|l|}
\hline & General Government Revenue (\% GDP) \\
\hline & 2002 & 2012 \\
\hline Brazil & 34.44 & 35.41 \\
\hline China & 15.69 & 28.36 \\
\hline India & 17.73 & 19.72 \\
\hline South Africa & 23.75 & 27.21 \\
\hline OECD & 34.34 & 35.46 \\
\hline
\end{tabular}

Source: IMF 2015b 
Table 4 - Public and private expenditure on health as a proportion of GDP

\begin{tabular}{|l|l|l|l|l|l|l|}
\hline & \multicolumn{2}{|l|}{2002} & 2014 & \\
\hline & Public & Private & Total & Public & Private & Total \\
\hline Brazil & 3.18 & 3.9 & 7.1 & 3.83 & 4.5 & 8.3 \\
\hline India & 1.03 & 3.4 & 4.4 & 1.41 & 3.3 & 4.7 \\
\hline China & 1.71 & 3.1 & 4.8 & 3.10 & 2.5 & 5.5 \\
\hline South Africa & 3.23 & 4.6 & 8.1 & 4.24 & 4.9 & 8.8 \\
\hline
\end{tabular}

Source: WDI. Public health expenditure consists of recurrent and capital spending from government (central and local) budgets, external borrowings and grants (including donations from international agencies and nongovernmental organizations), and social (or compulsory) health insurance funds. Private health expenditure includes direct household (out-of-pocket) spending, private insurance, charitable donations, and direct service payments by private corporations. Total health expenditure is the sum of public and private health expenditure. It covers the provision of health services (preventive and curative), family planning activities, nutrition activities, and emergency aid designated for health but does not include provision of water and sanitation. 
Table 5 - Out-of-pocket Health Expenditure as a proportion of total health expenditure

\begin{tabular}{|l|l|l|}
\hline & 2002 & 2014 \\
\hline Brazil & 34.61 & 25.47 \\
\hline India & 70.50 & 62.42 \\
\hline China & 57.72 & 31.99 \\
\hline South Africa & 11.70 & 6.49 \\
\hline
\end{tabular}

Source: WDI 
Table 6 - Public expenditure on education as a proportion of GDP

\begin{tabular}{|l|l|l|}
\hline & 1999 & 2012 \\
\hline Brazil & 3.78 & 5.91 \\
\hline India & 4.34 & 3.82 \\
\hline China & 1.90 & $3.91^{*}$ \\
\hline South Africa & 5.88 & 6.36 \\
\hline
\end{tabular}

Source: WDI. *The data for China in 2012 are based on the authors' calculation on the basis of the figures taken from the China Statistical Yearbook 2014. 
Table 7 - Combined health and education public expenditure as a proportion of the GDP

\begin{tabular}{|l|l|l|l|}
\hline & 1999 & 2012 & Change \\
\hline Brazil & 6.73 & 9.57 & $+42.2 \%$ \\
\hline India & 5.47 & 5 & $-8.6 \%$ \\
\hline China & 3.73 & $6.85^{*}$ & $+83.6 \%$ \\
\hline South Africa & 9.3 & 10.63 & $+14.3 \%$ \\
\hline
\end{tabular}

Source: WDI. *The education component of the China figure in 2012 is calculated by the authors on the basis of the figures taken from the China Statistical Yearbook 2014. 
Table 8 - Social expenditure ca. 2005 - ca. 2010

\begin{tabular}{|l|l|l|}
\hline Country & 2005 & 2010 \\
\hline Brazil & 0.83 & 1.09 \\
\hline India & 0.4 & 1.5 \\
\hline China & 4.9 & 5.4 \\
\hline South Africa & 3.6 & 4.4 \\
\hline
\end{tabular}

Sources: For India and China: Asian Development Bank: Social protection Index Database. For Brazil: Castro, Ribeiro, Chaves \& Duarte 2012. For South Africa: Reserve Bank of South Africa database. 
Table 9 - Percentages of total person-days worked

\begin{tabular}{|l|l|l|}
\hline & Scheduled Castes & Scheduled Tribes \\
\hline Share of person-days, 2006-08 & $25-31 \%$ & $24-36 \%$ \\
\hline Share of person-days, 2008-12 & $28.8 \%$ & $21.3 \%$ \\
\hline Share of population & $16.2 \%$ & $8.2 \%$ \\
\hline
\end{tabular}

Source: MGNREGA website: nrega.nic.in, 'DMU reports' ${ }^{14}$

${ }^{14}$ This is discussed in much greater detail in chapters six and eight of Jenkins and Manor (2017). 
Table 10 - Gini coefficient 1993-2009/13

\begin{tabular}{|l|l|l|l|}
\hline & 1993 & $\begin{array}{l}\text { Most recent data } \\
(2009 / 13)\end{array}$ & $\begin{array}{l}\text { Most recent data with } \\
\text { income-based Gini for India }\end{array}$ \\
\hline Brazil & 60.12 & 52.67 & 52.67 \\
\hline India & 30.82 & 33.9 & $52.7^{*}$ \\
\hline China & 35.5 & 42.06 & 42.06 \\
\hline South Africa & 59.33 & 63.38 & 63.38 \\
\hline
\end{tabular}

Sources: WDI. Brazil's most recent data: 2013; India: 2009; China: 2010; South Africa: 2011. *This figure comes from the Indian Human Development Survey (Desai et al. 2010). That figure differs from the figures in column two of the table because it is based on income while the figures in column two are based on consumption. 
Table 11 - Wealth Inequality (Gini of wealth inequality) 2010-15

\begin{tabular}{|l|l|l|}
\hline & 2010 & 2015 \\
\hline Brazil & 79.6 & 83 \\
\hline India & 77.8 & 83.1 \\
\hline China & 69 & 73.3 \\
\hline South Africa & 81.6 & 84 \\
\hline
\end{tabular}

Source: Credit Suisse 2015 
Table 12 - Life expectancy at birth

\begin{tabular}{|l|l|l|l|l|}
\hline \multicolumn{5}{|l|}{ Life expectancy at birth (years) } \\
\hline & 2000 & 2014 & \\
\hline & Total & Female & Total & Female \\
\hline Brazil & 70 & 73.9 & 74.4 & 78.2 \\
\hline China & 71.7 & 73.4 & 75.8 & 77.3 \\
\hline India & 62.6 & 63.5 & 68 & 69.5 \\
\hline South Africa & 55.8 & 58 & 57.2 & 59.3 \\
\hline
\end{tabular}

Source: WDI 
TABLE 13 - IMR and CMR 2000-14

\begin{tabular}{|l|l|l|l|l|l|l|}
\hline & \multicolumn{2}{|l|}{$\begin{array}{l}\text { Infant Mortality Rate } \\
\text { (per 1,000 live births) }\end{array}$} & $\begin{array}{l}\text { \% } \\
\text { Change }\end{array}$ & \multicolumn{2}{l|}{$\begin{array}{l}\text { Child Mortality Rate } \\
\text { (per 1,000 live births) }\end{array}$} & $\begin{array}{l}\text { \% } \\
\text { Change }\end{array}$ \\
\hline & 2000 & 2014 & $2000-14$ & 2000 & 2014 & $2000-14$ \\
\hline Brazil & 28.1 & 14.4 & -48.75 & 32 & 16.2 & -49.38 \\
\hline China & 30.2 & 9.8 & -67.55 & 36.9 & 11.4 & -69.11 \\
\hline India & 66.4 & 39.3 & -40.81 & 91.2 & 49.8 & -45.39 \\
\hline South Africa & 54 & 34.4 & -36.30 & 75.3 & 43.4 & -42.36 \\
\hline
\end{tabular}

Source: WDI 
Table 14 - Immunisation rates

\begin{tabular}{|l|l|l|l|l|}
\hline Country & \multicolumn{4}{|l|}{ Immunization rates (\% children 12-23 months) } \\
\hline & DPT & 2013 & Measles \\
\hline & 2000 & 95 & 2000 & 2013 \\
\hline Brazil & 98 & 99 & 99 & 99 \\
\hline China & 85 & 72 & 84 & 99 \\
\hline India & 60 & 68 & 59 & 74 \\
\hline $\begin{array}{l}\text { South } \\
\text { Africa }\end{array}$ & 73 & 68 & 72 & 79 \\
\hline
\end{tabular}

Source: WDI 
Table 15 - Stunting rates

\begin{tabular}{|l|l|l|}
\hline \multirow{4}{*}{ Brazil } & Year & $\begin{array}{l}\text { \% Children under 5 } \\
\text { who are stunted }\end{array}$ \\
\hline \multirow{3}{*}{ China } & 1996 & 13.5 \\
\cline { 2 - 3 } & 2006 & 7.1 \\
\hline India & 2000 & 17.8 \\
\cline { 2 - 3 } & 2010 & 9.4 \\
\hline \multirow{3}{*}{ South Africa } & 1998 & 54.2 \\
\cline { 2 - 3 } & 2005 & 47.9 \\
\cline { 2 - 3 } & 2013 & $38.7 *$ \\
\cline { 2 - 3 } & 2099 & 30.1 \\
\hline
\end{tabular}

Source: WHO-UNICEF-World Bank dataset. *This is based on UNICEF's Rapid Survey on Children. 
Table 16 - Literacy and youth literacy rates

\begin{tabular}{|l|l|l|l|l|l|l|l|}
\hline Country & Year & \multicolumn{2}{l|}{$\begin{array}{l}\text { Literacy rates (\% people } \\
\text { above 15) }\end{array}$} & \multicolumn{2}{l|}{$\begin{array}{l}\text { Youth literacy rates (\% of people } \\
\text { 15-24) }\end{array}$} \\
\hline \multirow{3}{*}{ Brazil } & & Female & Male & Total & Female & Male & Total \\
& 2000 & 86.5 & 86.23 & 86.37 & 95.72 & 92.65 & 94.18 \\
\cline { 2 - 8 } & 2012 & 91.63 & 91.02 & 91.33 & 99.02 & 98.22 & 98.62 \\
\hline \multirow{3}{*}{ China } & 2000 & 86.53 & 95.14 & 90.92 & 98.50 & 99.20 & 98.86 \\
\cline { 2 - 8 } & 2010 & 92.71 & 97.48 & 95.12 & 99.59 & 99.69 & 99.64 \\
\hline \multirow{3}{*}{ India } & 2001 & 47.84 & 73.41 & 61.01 & 67.75 & 84.19 & 76.43 \\
\cline { 2 - 8 } & $2011^{*}$ & 65.46 & 82.14 & 74.04 & 81.8 & 90 & 86.1 \\
\hline \multirow{2}{*}{$\begin{array}{l}\text { South } \\
\text { Africa }\end{array}$} & 1996 & 80.93 & 84.07 & 82.40 & 94.29 & 93.50 & 93.91 \\
\cline { 2 - 8 } & 2012 & 92.59 & 94.96 & 93.73 & 99.27 & 98.50 & 98.99 \\
\hline
\end{tabular}

Source: WDI. * 2011 data for India are taken from the 2011 census. 
Table 17 Maternal mortality rates

\begin{tabular}{|l|l|l|l|l|}
\hline & \multicolumn{2}{|l|}{$\begin{array}{l}\text { Maternal mortality rate (per } \\
100,000 \text { live births) }\end{array}$} & \multicolumn{2}{l|}{$\begin{array}{l}\text { Births attended by skilled health } \\
\text { staff }(\%)\end{array}$} \\
\hline & 2003 & $2012-13$ & Around 2000* & $\begin{array}{l}\text { Most recent } \\
\text { data** }\end{array}$ \\
\hline Brazil & 72 & 58.2 & 96.5 & 98.1 \\
\hline China & 51 & 23.2 & 96.6 & 99.9 \\
\hline India & 301 & 170 & 42.5 & 52.3 \\
\hline South Africa & 165.5 & 200 & 84.4 & 94.3 \\
\hline
\end{tabular}

Source: WDI. * Data for Brazil: 2001; China and India: 2000; South Africa: 1998. ** Brazil: 2012;

China: 2013; India and South Africa: 2008 